\title{
Study on Effect of Organic Manures on Quality and Biochemical Traits of Strawberry (Fragaria $\times$ ananassa Duch.) under Naturally Ventilated Polyhouse
}

\author{
B. J. Sahana ${ }^{1 *}$, D. Madaiah ${ }^{2}$, S. Sridhara ${ }^{3}$, S. Pradeep ${ }^{4}$ and K. M. Nithin ${ }^{5}$
}

${ }^{1}$ Department of Fruit Science, ${ }^{2}$ Department of Post harvest Technology, ${ }^{3}$ Department of Agronomy, ${ }^{4}$ Organic Farming Research Center, ${ }^{5}$ Department of Fruit Science, University of Agricultural and Horticultural Sciences, Shivamogga, Karnataka, India

*Corresponding author

\section{A B S T R A C T}

\begin{tabular}{|l|}
\hline Ke y w o r d s \\
Berry, VC, FYM, \\
Jeevamruth, \\
Beejamruth and \\
Strawberry
\end{tabular}

\section{Introduction}

Strawberry (Fragaria ×ananassa Duch.) is the most delicious and refreshing fruit. It is cherished in the garden for its beautiful red berries that has a tantalizing aroma. The fruits are widely acclaimed for its pleasant flavor, conspicuous colour and varied blend of taste. All cultivated varieties of strawberry are octaploid $(2 n=56)$ in nature and belongs to the family Rosaceae. It is a short day plant, originated from France and the two American diploids Fragaria chiloensis and Fragaria virginiana are considered as its progenitors (Staudt, 1989). There are about 20 recognized species of strawberry in five different chromosome groups, comprising ten diploids, four tetraploids, one pentaploid, one hexaploid and four octaploids. Strawberries contain over 90 per cent water, 7 per cent of carbohydrates, less than 1 per cent each of protein and fat and 2 per cent fibre. The fresh ripe fruits of strawberry are a rich source of vitamins and minerals. Fruit is fairly good source of vitamin A (60 IU/100g), vitamin C $(30-120 \mathrm{mg} / 100 \mathrm{~g})$, pectin $(0.55 \%)$, iron, 
potassium, calcium, phosphorous, total soluble solids $(7-12 \%)$, total sugars $(5.0 \%)$ and acids (0.90-1.85\%). Strawberry possess anticancerous compound called ellagic acid (Wange and Kzlogoz, 1998). In addition to fresh consumption it is used in fruit processing units for preparation of jam, syrup, dairy products such as yoghurts, milkshakes, ice creams, flavoured milk and smoothies. Being a rich source of vitamins and minerals coupled with delicate flavour, strawberry has now become an important table fruit of millions of people around the world. Strawberry being a non-climacteric fruit, it matures only on plant (Cordenunsi et al., 2005).Based on bearing seasons, it is grouped under three categories as June bearing, everbearing and day-neutral strawberries. Strawberries are in great demand for fresh market and its popularity can be judged by the phenomenal increase in yield due to the changes in production pattern like intensive culture system, adoption of day neutral cultivars and choice of appropriate environment.

The current global scenario of firmly emphasizes the need to adopt eco-friendly agricultural practices for sustainable food production. The use of organic manures in such situation is, therefore practically a paying proposal. Organic farming is a holistic way of farming with the aim of conserving the natural resources. Organic manures like Beejamruth, Jeevamruth, Vermicompost and FYM etc. have been utilized in agriculture as a significant source of organic manure. Organic manures improve the physical properties of soil apart from increasing the population of beneficial microorganism. Organic agriculture has grown during the last decade and continues to grow as consumers become increasingly concerned about the negative impacts of conventional farming practices on human health and the environment. The Jeevamruth and Beejamruth are eco-friendly organic preparations made from cow products. The use of organic liquid products such as Beejamruth and Jeevamruth result in higher growth, yield and quality of crops. These liquid organic solutions are prepared from cow dung, urine, milk, curd, ghee, legume flour and jaggary. They contain macro nutrients, essential micro nutrients, many vitamins, essential amino acids, growth promoting factors like IAA, GA and beneficial microorganisms (Palekar, 2006 and Natarajan, 2007). Jeevamruth promotes immense biological activity in soil and makes the nutrients available to crop. Beejamruth protects the crop from soil borne pathogens (Devakumar et al., 2008).Vermicompost and FYM applications are also known to increase Strawberry plant growth and yield. Vermicompost and FYM applications in strawberries can increase beneficial microbial populations, which enhance the production of plant growth hormones (auxin, gibberellins and cytokinins) and humic acids. Several experiments in strawberry have indicated that these hormones and acids may improve plant growth viz.,leaf area, shoot biomass, number of flowers and runners (Arancon et al., 2004) and yield (Arancon et al., 2004 and Singh et al., 2008). The studies made to understand the combined application of Jeevamrutha and Beejamrutha along with organic manures is lacking. Hence the present investigation aims to understand the influence of combined application of these organic manure on fruit quality aspects of strawberry grown under naturally ventilated polyhouse.

\section{Materials and Methods}

Experiment was conducted in a naturally ventilated polyhouse at the Department of Fruit Science, College of Horticulture, Mudigere coming under the jurisdiction of the University of Agricultural and Horticultural Sciences, Shivamogga, Karnataka, India during 2019-2020. Mudigere is situated in the 
Western Ghats, represents the typical climate of Hill zone (Zone- 9 and Region- V) of Karnataka. It is located at $13^{\circ} 7^{\prime}$ North latitude and $74^{\circ} 37^{\prime}$ East longitude with an altitude of $980 \mathrm{~m}$ above mean sea level (MSL).

The pots were filled with media viz., Soil: Vermicompost: Vermiculite: Cocopeat in the ratio of $1: 1: 1: 1$ on volume $(\mathrm{v} / \mathrm{v})$ basis. The test variety was "winter dawn" and the planting was taken up on $7^{\text {th }}$ November 2019.

The design applied for the study was Randomized Complete Block Design (RCBD) with three replications and nine treatments. The different organic manure treatment combination includes $T_{1}-100$ per cent RDN through FYM, $\mathrm{T}_{2}-100$ per cent RDN through FYM + Jeevamruth @ $500 \mathrm{ml}$ per pot at two stages, $\mathrm{T}_{3}-100$ per cent RDN through FYM + Beejamruth seedling treatment, $\mathrm{T}_{4}-100$ per cent RDN through FYM + Jeevamruth @ 500 $\mathrm{ml}$ per pot at two stages + Beejamruthseedling treatment, $\mathrm{T}_{5}-100$ per cent RDN through vermicompost, $\mathrm{T}_{6}-100$ per cent $\mathrm{RDN}$ through vermicompost + Jeevamruth @ $500 \mathrm{ml}$ per pot at two stages, $\mathrm{T}_{7}-100$ per cent RDN through vermicompost + Beejamruth seedling treatment, $\mathrm{T}_{8}-100$ per cent $\mathrm{RDN}$ through vermicompost + Jeevamruth @500 ml per pot at two stages + Beejamruth seedling treatment and $\mathrm{T}_{9}$-Recommended Dose of Fertilizers (150:100:120 kg/ha).

Jeevamruth @ $500 \mathrm{ml}$ per plant is drenched at two stages i.e., flowering and fruit development stage. Seedling roots were dipped in Beejamruth for 12 hours before transplanting. Vermicompost supplies 1.25 per cent Nitrogen, so 100 per cent RDN is supplied by applying $21 \mathrm{~g}$ of $\mathrm{VC}$ per pot at flowering and fruit development stage. 100 per cent RDN is supplied by applying $52.5 \mathrm{~g}$ of FYM per pot at flowering and fruit development stage.
The effect of organic manures application observed by determining the different biochemical traits like Total Soluble Solids ( ${ }^{\mathbf{0}}$ Brix), Ascorbic acid (mg100 $\mathrm{g}^{-1)}$, Sugars: acid ratio, Total sugars (\%), chlorophyll-a (mg $\left.\mathrm{g}^{-1}\right)$, chlorophyll-b $\left(\mathrm{mg} \mathrm{g}^{-1}\right)$, total chlorophyll content (mg $\mathrm{g}^{-1)}$, Shelf life (Days), Fruit growth rate $\left(\mathrm{cm} \mathrm{day}^{-1}\right)$ and Titratable acidity (\%) were recorded. Standard methods designed for the quality analysis were followed for analysis of fruit quality traits (Ranganna, 1995). The data subjected to statistical analysis for drawing conclusion $(\mathrm{p}=5 \%)$.

\section{Results and Discussion}

Application of organic manures significantly influenced the fruit quality parameters of strawberry (Table $1 \& 2$ 2).The significantly highest reducing sugar, non-reducing sugar and total sugars content of 4.819, 2.749 and 7.568 per cent, highest Total Soluble Solids (8.030 ${ }^{\circ}$ Brix), maximum chlorophyll-a (1.910 $\left.\mathrm{mg} \mathrm{g}^{-1}\right)$, chlorophyll-b (0.769 $\left.\mathrm{mg} \mathrm{g}^{-1}\right)$, total chlorophyll content $\left(2.679 \mathrm{mg} \mathrm{g}^{-1)}\right.$, and highest sugars to acid ratio of 9.240were recorded in treatment which received 100 per cent RDN through Vermicompost + Jeevamruth at $500 \mathrm{ml}$ pot $^{-1}+$ Beejamruth seedling treatment $\left(\mathrm{T}_{8}\right)$. The increase in the content of sugars, chlorophyll content and Total Soluble Solids of fruits might be due to the vermicompost application as it fasten the metabolic transformation of starch and pectin into soluble compounds and rapid translocation of sugars from leaves to the developing fruits and also due to increased micro nutrients, macro nutrients, carbohydrate (\%) and protein (\%) content. Also, the potassium (K) promotes sugar accumulation in berries and balance of $\mathrm{N}, \mathrm{P}$ and $\mathrm{K}$ found essential for proper sugar accumulation of fruits, the increase in total sugars ultimately yielded higher sugars to acid ratio. These findings are in agreement with the results of 
Ghazvini et al., (2007), Attia et al., (2009) and Khalid et al., (2013).

The maximum ascorbic acid (58.749 $\mathrm{mg} / 100 \mathrm{~g}$ ) was recorded in $\mathrm{T}_{8}-100$ per cent RDN through Vermicompost + Jeevamruth at $500 \mathrm{ml}$ pot $^{-1}+$ Beejamruth seedling treatment while, minimum ascorbic acid (51.950 $\mathrm{mg} / 100 \mathrm{~g}$ ) was recorded in with the application of Recommended Dose of
Fertilizers (Control- $T_{9}$ ). Increase in ascorbic acid content might be due to the availability of micro and macronutrients and increased efficiency of microbial inoculants to fix atmospheric nitrogen, increase in availability of phosphorous and secretion of growth promoting substances which accelerates the physiological process like carbohydrates synthesis, etc.

Table.1 Effect of organic manures on quality, leaf chlorophyll content and yield of strawberry under naturally ventilated playhouse

\begin{tabular}{|c|c|c|c|c|c|c|}
\hline \multirow[t]{2}{*}{ Treatment } & \multirow{2}{*}{$\begin{array}{c}\text { TSS } \\
\left({ }^{(} \text {Brix }\right)\end{array}$} & \multirow{2}{*}{$\begin{array}{l}\text { Fruit growth } \\
\text { rate }\left(\mathrm{cm} \mathrm{day} \text { day }^{-1}\right)\end{array}$} & \multicolumn{3}{|c|}{ Chlorophyll content $\left(\mathrm{mgg}^{-1}\right)$} & \multirow{2}{*}{$\begin{array}{l}\text { Yield per } \\
\text { plant (g) }\end{array}$} \\
\hline & & & Chlorophyll-a & Chlorophyll- b & $\begin{array}{c}\text { Total } \\
\text { chlorophyll }\end{array}$ & \\
\hline$T_{1}$ & 6.350 & 0.150 & 1.520 & 0.452 & 1.970 & 220.49 \\
\hline $\mathbf{T}_{2}$ & 7.420 & 0.183 & 1.650 & 0.609 & 2.261 & 273.85 \\
\hline $\mathbf{T}_{3}$ & 6.870 & 0.165 & 1.570 & 0.528 & 2.100 & 251.13 \\
\hline $\mathbf{T}_{4}$ & 7.850 & 0.184 & 1.797 & 0.719 & 2.528 & 320.35 \\
\hline$T_{5}$ & 6.630 & 0.151 & 1.550 & 0.492 & 2.040 & 240.93 \\
\hline$T_{6}$ & 7.609 & 0.179 & 1.719 & 0.649 & 2.371 & 295.17 \\
\hline $\mathbf{T}_{7}$ & 7.030 & 0.173 & 1.609 & 0.559 & 2.171 & 260.01 \\
\hline $\mathbf{T}_{8}$ & 8.030 & 0.192 & 1.910 & 0.769 & 2.679 & 350.79 \\
\hline$T_{9}$ & 6.221 & 0.144 & 1.482 & 0.411 & 1.890 & 198.89 \\
\hline S. Em \pm & 0.010 & 0.001 & 0.002 & 0.003 & 0.004 & 0.73 \\
\hline CD@ 5\% & 0.032 & 0.003 & 0.007 & 0.008 & 0.013 & 2.20 \\
\hline
\end{tabular}

Table.2 Effect of organic manures on biochemical parameters of strawberry under naturally ventilated polyhouse

\begin{tabular}{|c|c|c|c|c|c|c|}
\hline Treatment & $\begin{array}{c}\text { Reducing } \\
\text { sugar (\%) }\end{array}$ & $\begin{array}{c}\text { Non } \\
\text { reducing } \\
\text { sugar }(\mathbf{\%})\end{array}$ & $\begin{array}{c}\text { Total } \\
\text { sugar } \\
(\mathbf{\%})\end{array}$ & $\begin{array}{c}\text { Titratable } \\
\text { acidity } \\
(\mathbf{\%})\end{array}$ & $\begin{array}{c}\text { Ascorbic } \\
\text { acid } \\
\text { (mg/100 g) }\end{array}$ & $\begin{array}{c}\text { Shelf } \\
\text { life } \\
\text { (days) }\end{array}$ \\
\hline $\mathbf{T}_{\mathbf{1}}$ & 3.380 & 2.121 & 5.501 & 1.321 & 52.850 & 2.18 \\
\hline $\mathbf{T}_{\mathbf{2}}$ & 3.950 & 2.341 & 6.291 & 1.070 & 55.181 & 2.87 \\
\hline $\mathbf{T}_{\mathbf{3}}$ & 3.720 & 2.211 & 5.931 & 1.311 & 53.589 & 2.56 \\
\hline $\mathbf{T}_{\mathbf{4}}$ & 4.410 & 2.679 & 7.089 & 0.950 & 56.130 & 3.31 \\
\hline $\mathbf{T}_{\mathbf{5}}$ & 3.550 & 2.140 & 5.690 & 1.271 & 53.472 & 2.34 \\
\hline $\mathbf{T}_{\mathbf{6}}$ & 4.100 & 2.579 & 6.679 & 1.020 & 55.311 & 3.03 \\
\hline $\mathbf{T}_{\mathbf{7}}$ & 3.809 & 2.321 & 6.130 & 1.120 & 54.231 & 2.72 \\
\hline $\mathbf{T}_{\mathbf{8}}$ & 4.819 & 2.749 & 7.568 & 0.819 & 58.749 & 3.52 \\
\hline $\mathbf{T}_{\mathbf{9}}$ & 3.130 & 1.870 & 5.000 & 1.579 & 51.950 & 1.78 \\
\hline $\mathbf{S . ~} \mathbf{E m} \mathbf{C D} @ \mathbf{5 \%}$ & 0.008 & 0.005 & 0.011 & 0.004 & 0.033 & 0.01 \\
\hline
\end{tabular}


Fig.1 General view of the experimental plot at reproductive stage

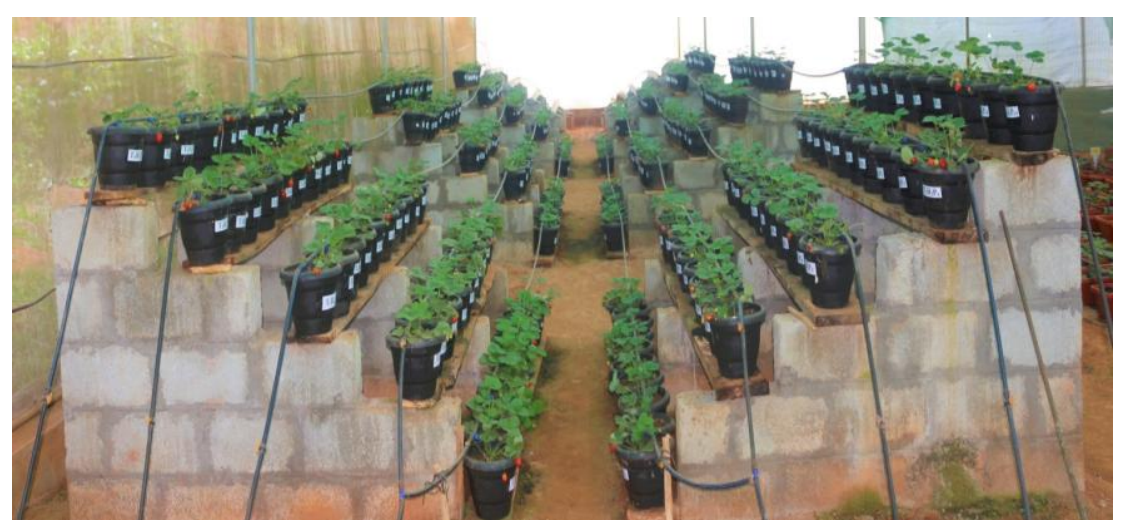

Fig.2 Fruiting of treatment eight

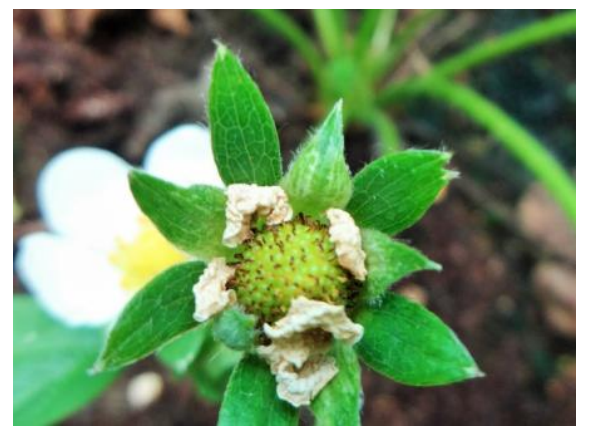

From this study, it can be concluded that application of Vermicompost + Jeevamruth @ $500 \mathrm{ml}$ per pot + Beejamruth seedling treatment recorded highest fruit yield per plant $(350.79 \mathrm{~g})$. These findings are in agreement with the results of Tripathi et al., (2010) and Chauhan et al., (2016).

The maximum shelf life (3.52 days) was observed in $\mathrm{T}_{8}-100$ per cent $\mathrm{RDN}$ through Vermicompost + Jeevamruth at $500 \mathrm{ml} \mathrm{pot}^{-1}+$ Beejamruth seedling treatment. The possible reason for reduction in weight loss and spoilage by microbial consortium might be due to reduced respiration of fruits as influenced by the presence of a higher amount of calcium and potassium resulting in increased the membrane integrity of fruits, so that the fruits could retain more water against

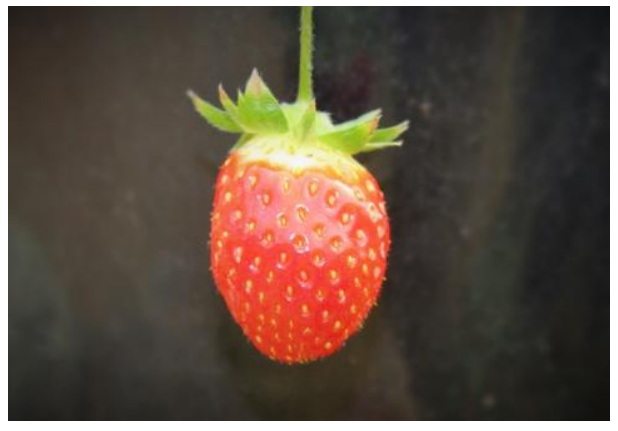

the force of evaporation and possibly they might have also altered some of the proteinaceous constituents. Beejamruth seedling treatment and application of vermicompost reduces the disorders and soil borne diseases like botrytis rot. These findings are in agreement with the results of Nileema and Sreenivasa (2010).

The maximum fruit growth rate $0.192 \mathrm{~cm} \mathrm{day}^{-}$ ${ }^{1}$ was observed in $\mathrm{T}_{8}-100$ per cent $\mathrm{RDN}$ through Vermicompost + Jeevamruth at 500 $\mathrm{ml}$ pot $^{-1}+$ Beejamruth seedling treatment. Highest fruit growth rate may be due to the use of combination of Vermicompost, Jeevamruth and Beejamruth, which influences physicochemical status of media combination and presence of available nutrients in the form of nitrate, phosphate, soluble potassium 
exchangeable calcium and magnesium which in turn helped the photosynthesis process, accumulation of photosynthates, their translocation to berries and level of hormones as well as synthesis of different growth regulators. The results are in conformity with Yadav et al., (2009) and Beer et al., (2017).

In conclusion the result of the present study revealed that cultivation of strawberry variety "winter dawn" by application of 100 per cent RDN through vermicompost + Jeevamruth @ $500 \mathrm{ml}$ per pot at two stages+Beejamruth seedling treatment found better for achieving not only yield levels of the fruit but also its quality parameters under naturally ventilated polyhouse.

\section{References}

Arancon, N. Q., Edwards, C. A., Bierman, P., Welch, C. and Metzger, J. D., 2004, The influence of vermicompost applications to strawberries: Part 1. Effects on growth and yield. Bioresour. Technol., 93: 145-153.

Attia, M., Ahmed, M.A. and El-Sanbaty, M.R2009, Use of biotechnologies to increase growth, productivity and fruit quality of Moghrabi banana under different rates of phosphorus. World $J$. Agric. Sci., 5: 211- 218.

Beer, K., Kumar, S., Alok, K., Gupta, and Syamal, M.M., 2017, Effect of Organic, Inorganic and Bio-Fertilizer on Growth, Flowering, Yield and Quality of Strawberry (Fragariax ananassa Duch.) cv. Chandler. Int. J. Curr. Microbiol. App. Sci., 6(5): 2932-2939.

Chauhan, K., Negi, M., Nautiyal, B.P., Abrol, G., Upadhyay, S. and Bhuguna, P., 2016, Effect of organic manures and growing conditions on plant growth, yield and quality of strawberry (Fragaria $\mathrm{x}$ ananassa Duch.). Indian J. Hortic., 71(3): 200-206.
Cordenunsi, B. R., Genovese, M. I., Nascimento, J. R., Hassimotto, N. M., Santos, R. J. and Lajolo, M., 2005, Effects of temperature on the chemical composition and antioxidant activity of three strawberry cultivars., J. Food Chem., 91: 113-121.

Devakumar, N., Rao, G. G. E., Shubha, S., Imrankhan, Nagaraj and Gowda, S. B., 2008, Activities of Organic Farming Research Centre. Navile, Shivamogga, Univ. Agri. Sci., Bangalore, Karnataka.

Ghazvini, R.F., Payvast, G. and Azarian, H., 2007, Effect of Clinoptilolitic-zeolite and Perlite Mixtures on the Yield and Quality of Strawberry in Soil-less Culture. Int. J. Agri. \&Bio.,9(6): 1-5.

Khalid, S., Khalid, M. Q., Ishfaq, H., Khalid, S. K. and Usman, S. Q., 2013, Effect of organic amendments on vegetative growth, fruit and yield quality of strawberry. Pak. J. Agric. $e$ Res., 26(2):104-112.

Natarajan, K., 2007, Panchagavya for plant. Proc. Nation. Conf. Glory Gomatha, Dec. 1-3, 2007, S. V. Veterinary Univ., Tirupati, pp.72-75.

Nileema, S. G. and Sreenivasa, M. N., 2010, Influence of liquid organic manures on growth, nutrient content and yield of tomato (Lycopersicon esculentum Mill.) in the sterilized soil. KarnatakaJ. Agric. Sci.,24(2): 153-157.

Palekar, S., 2006, Shoonyab and ovaladanaisargikakrushi, published by Swamy Anand, Agric. Prakashana, Bangalore, India.

Ranganna, S., 1995, Hand book of analysis and quality control for fruits and vegetable products. Mcgrow Hill Publishing Co. Ltd., New Delhi. pp. 121.

Singh, R., Sharma, R. R., Kumar, S., Gupta, R. K. and Patil, R. T., 2008, Vermicompost substitution influences growth, physiological disorders, fruit 
yield and quality of strawberry (Fragaria x ananassa Duch.). Bioresource Technol.,99: 8507-8511.

Staudt, G., 1989, The species of Fragaria, their taxonomy and geographical distribution. ActaHortic., 265: 23-33.

Tripathi, V.K., Kumar, N., Shukla, H.S. and Mishra, A.N., 2010, Influence of Azotobacter, Azospirillum and PSB on growth, yield and quality of strawberry cv. chandler. Abst: National Symposium on Conservation Hort., Dehradun, pp. 198- 199.

Wange, R. S. and Kzlogoz, G. A., 1998, Effect of biofertilizer on growth, yield and quality of Strawberry. Ann. Agric. Sci. Mosthohor, 43(2): 247-254.

Yadav, S.K., Khokhar, U.U. and Yadav, R.P., 2009. Integrated nutrient management for strawberry cultivation. Indian $J$. Hort.,67(4): 445-449.

\section{How to cite this article:}

Sahana, B. J., D. Madaiah, S. Sridhara, S. Pradeep and Nithin, K. M. 2020. Study on Effect of Organic Manures on Quality and Biochemical Traits of Strawberry (Fragariaxananassa Duch.) under Naturally Ventilated Polyhouse. Int.J.Curr.Microbiol.App.Sci. 9(10): 2692-2698. doi: https://doi.org/10.20546/ijcmas.2020.910.325 